\title{
Photosynthetic responses to UV-radiation of intertidal macroalgae from the Strait of Magellan (Chile)
}

\author{
Respuestas fotosintéticas a la radiación UV en algas intermareales del Estrecho de \\ Magallanes (Chile)
}

\section{RALF RAUTENBERGER ${ }^{1,2, *}$, ANDRÉS MANSILLA ${ }^{4}$, IVÁN GÓMEZ ${ }^{5}$, CHRISTIAN WIENCKE ${ }^{6}$ \& KAI BISCHOF 2,3}

\author{
${ }^{1}$ Institute for Polar Ecology, Christian Albrechts University of Kiel, Wischhofstrasse 1-3, \\ Building 12, D-24148 Kiel, Germany \\ ${ }^{2}$ Department of Marine Botany, University of Bremen, FB 2 (Biology/Chemistry), \\ Leobener Strasse NW 2, D-28359 Bremen, Germany \\ ${ }^{3}$ Center for Tropical Marine Ecology, Fahrenheitstrasse 6, D-28359 Bremen, Germany \\ ${ }^{4}$ Instituto de la Patagonia, Universidad de Magallanes, Avenida Bulnes 01855, Casilla 113-D, Punta Arenas, Chile \\ ${ }^{5}$ Instituto de Biología Marina, Universidad Austral de Chile, Facultad de Ciencias, Casilla 567, Valdivia, Chile \\ ${ }^{6}$ Alfred Wegener Institute for Polar and Marine Research, Section Seaweed Biology, Am Handelshafen 12, D-27570 \\ Bremerhaven, Germany \\ *e-mail for correspondence: rrautenberger@ipoe.uni-kiel.de
}

\begin{abstract}
For the first time, the photosynthetic performance of field-grown macroalgae from the Magellan Strait was evaluated with respect to their photoadaptation in the field and acclimation potential to ultraviolet radiation. Five macroalgal species were collected in the eulittoral and the upper sublittoral: Ulva intestinalis, Porphyra columbina, Adenocystis utricularis, Desmarestia confervoides and D. ligulata. Photosynthesis vs. irradiance (P-I) curves of macroalgae cultivated in the laboratory under low white light intensities more than a week were used to assess the acclimation potential to irradiance conditions in the field. Both, photosynthetic parameters referred to as maximum electron transport rate (ETRmax) and light saturation points of photosynthesis $\left(\mathrm{I}_{\mathrm{k}}\right)$ were species-specific and did not correlate with the position on the shore. $\mathrm{I}_{\mathrm{k}}$ ranging between 80 and $215 \mu \mathrm{mol}$ photons $\mathrm{m}^{-2} \mathrm{~s}^{-1}$ was indicative of moderate sun-adaptation in all studied species. The acclimation potential to UV-radiation was determined as the extent and the rates $\left(\mathrm{m}_{\mathrm{inh}}\right)$ of PSII inhibition (resulting from decreased maximum PSII-quantum yield $(\mathrm{Fv} / \mathrm{Fm})$ ) after four hours of UV-exposure and as the subsequent rates of recovery $\left(\mathrm{m}_{\text {rec }}\right)$ in dim PAR. The results suggest that photosynthesis of each species during UV-exposure was transiently down regulated rather than damaged. Furthermore, no reductions in ETRmax were detected after $4 \mathrm{~h}$ exposure to UV-A and UV-B-radiation, and consequently the Calvin cycle could not be affected. Thus, Fv/Fm was a more sensitive parameter than ETRmax explaining the photosynthetic UV acclimation. Both, the rates of inhibition and the rates of recovery were not correlated with the morpho-functional groups of macroalgae nor to their vertical distribution. Thus, although the capacity to acclimate to UV-radiation varied among the different species, data suggest that such responses are based on metabolic adjustments or possibly photoprotective strategies. In conclusion and taking into account the light adaptation characteristics, all species collected in the midlittoral and the upper sublittoral at the Strait of Magellan seem to be well acclimated to UV-B doses occurring at their habitat, which might be a pre-requisite to withstand enhanced solar UV-B during ozone depletion or summertime irradiance conditions.
\end{abstract}

Key words: UV-radiation, macroalgae, photosynthesis, photoacclimation, Strait of Magellan.

\section{RESUMEN}

La actividad fotosintética de algas provenientes del Estrecho de Magallanes fue medida por primera vez con el propósito de determinar su fotoadaptación en terreno y su potencial de aclimatación a la radiación ultravioleta. Cinco especies fueron recolectadas desde la zona eulitoral y sublitoral superior: Ulva intestinalis, Porphyra columbina, Adenocystis utricularis, Desmarestia confervoides y D. ligulata. Curvas de fotosíntesis versus irradiancia (P-I) medidas en algas cultivadas en el laboratorio por más de una semana fueron usadas para determinar la aclimatación potencial de las algas en su hábitat. Tanto las capacidades fotosintéticas, determinadas a través de la tasa máxima de transporte de electrones (ETRmax), como los puntos de saturación de fotosíntesis $\left(\mathrm{I}_{\mathrm{k}}\right)$ fueron especies-específicas, no observándose correlaciones con la distribución vertical de 
las algas. Valores de $\mathrm{I}_{\mathrm{k}}$ con rangos entre 80 y $215 \mu \mathrm{mol} \mathrm{m} \mathrm{m}^{-2} \mathrm{~s}^{-1}$ indicaron una moderada adaptación a la luz en todas las especies estudiadas. La aclimatación a la radiación UV fue determinada a través del grado de disminución del rendimiento cuántico máximo del PSII $(\mathrm{Fv} / \mathrm{Fm})$ y su subsiguiente tasa de recuperación. Los resultados sugieren que bajo exposición a la radiación UV, la fotosíntesis no es dañada sino más bien regulada a la baja de forma transitoria. Además, no se observaron reducciones en ETRmax después de $4 \mathrm{~h}$ de exposición a la radiación UV-A y UV-B, y por consiguiente el ciclo de Calvin pudo no ser afectado. De este modo, Fv/Fm fue un parámetro mucho más sensitivo que ETRmax para explicar la aclimatación de fotosíntesis a la radiación UV. Tanto las tasas de inhibición como las tasas de recuperación no estuvieron correlacionadas con grupos morfofuncionales ni con la distribución vertical. Por tanto, aunque la capacidad para aclimatar a la radiación UV varió entre las diferentes especies, los resultados sugieren que estas respuestas están basadas en ajustamientos metabólicos o posiblemente estrategias fotoprotectoras. En conclusión, y tomando en cuenta las características de adaptación a la luz, todas las especies colectadas en el mesolitoral y sublitoral del Estrecho de Magallanes están bien aclimatadas a las dosis de UV-B que ocurren en su hábitat, lo cual es un prerrequisito para tolerar aumentos de UV-B durante disminución de ozono o durante condiciones de alta radiación en verano.

Palabras clave: radiación UV, macroalgas, fotosíntesis, fotoaclimatación, Estrecho de Magallanes.

\section{INTRODUCTION}

Chemical processes in the stratosphere over Antarctica lead to an annual depletion of ozone concentration in austral springtime since 1979 (Farman et al. 1985). When the ozone concentration in the air-column falls below the threshold of 220 Dobson Units, the so-called ozone hole develops (Stolarski et al. 1990). Ground-based measurements revealed a dramatic springtime loss of total ozone by $\approx 30 \%$ over Antarctica in 1979 compared with normal conditions (Farman et al. 1985). As soon as the polar vortex over the Antarctic breaks down in late spring, the ozone-poor air mass may move towards the southern tip of South America (Thompson 1991, Casiccia et al. 2003). Several times, the area of the Antarctic ozone hole has reached record sizes of more than 28 million $\mathrm{km}^{2}$, e.g., in the years 1998, 2000, 2003 and 2006 (Newman et al. 2007). Since the beginning of the 1990s, in September and October the Antarctic ozone hole has transiently extended as far north as to the southernmost regions of South America, e.g., Ushuaia (in 1990) and Punta Arenas (in 1993) (Casiccia et al. 2003). The most important consequence of low stratospheric ozone concentrations is the increase of solar UV-B-radiation on the Earth's surface (Casiccia et al. 2003), which is also affecting to aquatic environments (Tedetti \& Sempéré 2006).

Irradiance conditions in aquatic environments depend on multiple factors such as optical properties of the water body, the time of day, season and cover of the sky by clouds
(Kirk 1994). Thus, marine organisms are exposed to rapidly changing irradiance conditions. In the case of (adult) macroalgae, which are strictly sessile, diverse metabolic mechanisms (e.g., photoacclimation and inhibition of photosynthesis) have been identified as a way to avoid impairments induced by UV-radiation (reviewed by Bischof et al. 2006).

Although various studies have hitherto investigated the response of macroalgae to UVradiation in relation to their vertical distribution in temperate and polar regions (Bischof et al. 1999, Gómez et al. 2004, Rautenberger \& Bischof 2006), no information is available about photoadaptation and acclimation potential of photosynthesis to UVradiation of adult macroalgae occurring at Strait of Magellan (Mansilla et al. 2006) or southernmost Patagonia (Rautenberger \& Bischof 2006), a region especially affected by transient Antarctic ozone hole (Casiccia et al. 2003).

The goal of this study was to examine the light adaptation status of macroalgal assemblages of the Magellan region, which may be primary targets of enhanced solar UV-B radiation with important consequences for the whole coastal ecosystem (Häder et al. 2007). An experiment to evaluate UV-susceptibility of photosynthesis of macroalgae growing at Strait of Magellan was conducted. This study represents a first attempt in order to gain insights into potential mechanisms of photobiological acclimation and tolerance in macroalgal assemblages exposed naturally to enhanced UV-B radiation. 


\section{MATERIAL AND METHODS}

\section{Algal material and experimental conditions}

Five different macroalgal species (Table 1) from the tidal zone of the Strait of Magellan were collected at Punta Santa Ana $\left(53.50^{\circ} \mathrm{S}\right.$, $\left.70.93^{\circ} \mathrm{W}\right)$ during late austral summer on $16^{\text {th }}$ and $29^{\text {th }}$ March 2005 (Fig. 1). Immediately after sampling, specimens were transported in a cooled and dark box to the laboratory of the Department of Science and Natural Resources of the Institute of Patagonia at the Universidad de Magallanes in Punta Arenas (Chile). Macrothalli were raised in air-bubbled Provasoli enriched seawater (Provasoli 1968) in a climate room at $8 \pm 1{ }^{\circ} \mathrm{C}$ with artificial radiation of $20 \mu \mathrm{mol}$ photons $\mathrm{m}^{-2} \mathrm{~s}^{-1} \mathrm{PAR}$ (provided by one True Light Natural Daylight fluorescent tube, Osram, Germany). The temperature of the cultivation room was set up to the water temperature of the Strait of Magellan during summer according to the Meteorological Service of the Chilean Navy (www.shoa.cl/cendhoc/atlas/index.htm). Macroalgae were cultivated in the laboratory between eight and 13 days until experimentation. However, Desmarestia ligulata was used for UV-experiment one day after sampling. For UV-exposure experiments, algae were divided and spread out in a thin layer of macrothalli in Petri dishes to minimize self-shading. After $12 \mathrm{~h}$ of pre-incubation at 15 $\mu \mathrm{mol}$ photons $\mathrm{m}^{-2} \mathrm{~s}^{-1} \mathrm{PAR}$ (provided by one
True Light Natural Daylight fluorescent tube, Osram, Germany), radiation was supplemented with UV-A (provided by three UV-A-340 fluorescent tubes, Q-Panel Lab Products, Cleveland, USA) and UV-B radiation (provided by three TL20W/12RS, Philips, The Netherlands) for $4 \mathrm{~h}$. By the use of different cut-off filters algae were either exposed to PAR alone (controls, $\lambda \geq 400 \mathrm{~nm}$, achieved by Ultraphan URUV, Digefra, Munich, Germany), to PAR + UV-A $(\lambda \geq 320 \mathrm{~nm}$, Folanorm SF-AS, Folex, Cologne, Germany) or to PAR + UV-A + UV-B $(\lambda \geq 295 \mathrm{~nm}$, Ultraphan URT, Digefra, Munich, Germany). The light regime of the experimental set-up during UV-exposure is summarized in Table 2 and the spectral composition in Fig. 2. In order to study effects of UV radiation (particularly UV-B radiation) on macroalgal photosynthesis exclusively, intensities of PAR were kept low at about 17 $\mu$ mol photons $\mathrm{m}^{-2} \mathrm{~s}^{-1}$. Under such unrealistic radiation conditions, $U V$-effects on photosynthesis remain unmasked by high PAR induced effects as observed under natural radiation conditions. Light intensities and UVirradiances were measured using an UV/VIS spectroradiometer (Ramses ACC Hyperspectral Sensor, TriOS GmbH, Oldenburg, Germany). The integral dose of exposed UV-B radiation (PAR + UV-A + UV-B, unweighted) over the entire experimental time $(4 \mathrm{~h})$ was $25.55 \mathrm{~kJ} \mathrm{~m}^{-2}$. The biologically effective dose of $0.82 \mathrm{~kJ} \mathrm{~m}^{-2} 4$ $\mathrm{h}^{-1}$ [according to the model for generalized plant damage of Caldwell (1971)] was chosen

TABLE 1

Macroalgal species used in the experiment, morpho-functional groups and depth distribution in the tidal zone at Punta Santa Ana (Strait of Magellan) near Punta Arenas, Chile

Especies usadas en los experimentos, grupos morfofuncionales y su distribución en profundidad en la zona intermareal de Punta Santa Ana (Estrecho de Magallanes) cerca de Punta Arenas, Chile

\begin{tabular}{|c|c|c|c|}
\hline Species & Algal class & $\begin{array}{l}\text { Position on the shore" } \\
\text { at "Punta Santa Ana }\end{array}$ & $\begin{array}{l}\text { Morpho-functional } \\
\text { group of thalli }\end{array}$ \\
\hline Ulva intestinalis $\mathrm{L}$. & Ulvophyceae & Eulittoral & Sheet-like (tubular) \\
\hline Porphyra columbina Montagne & Bangiophyceae & Eulittoral & Sheet-like \\
\hline $\begin{array}{l}\text { Adenocystis utricularis (Bory de Saint-Vincent) } \\
\text { Skottsberg }\end{array}$ & Phaeophyceae & Eulittoral & Leathery (saccate) \\
\hline $\begin{array}{l}\text { Desmarestia confervoides (Bory de Saint-Vincent) } \\
\text { M. Ramírez \& A. Peters }\end{array}$ & Phaeophyceae & Upper sublittoral & Terete, branched \\
\hline Desmarestia ligulata (Lightfood) Lamouroux & Phaeophyceae & Upper sublittoral & Leathery \\
\hline
\end{tabular}




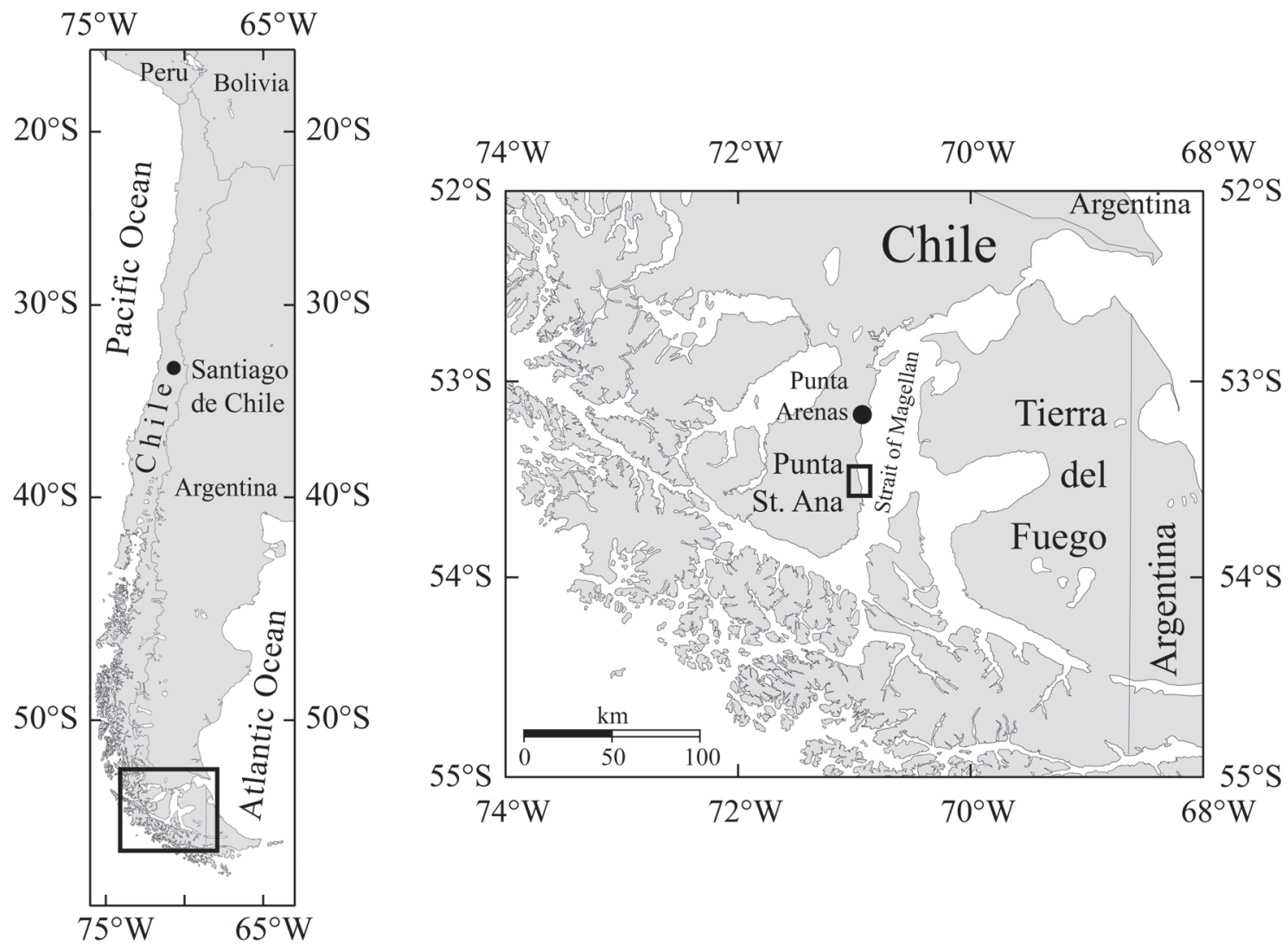

Fig. 1: Sampling site of used macroalgal species at Punta Santa Ana, $60 \mathrm{~km}$ south of Punta Arenas at Strait of Magellan, Chile.

Sitio de recolección de macroalgas en Punta Santa Ana, 60 km al sur de Punta Arenas en el Estrecho de Magallanes, Chile.

TABLE 2

Light regime in the experimental treatments measured by an UV/VIS spectroradiometer (Ramses ACC, TriOS GmbH, Oldenburg, Germany). Weighted UV-B irradiances were calculated by multiplying the action spectra for generalized plant damage response according to Caldwell (1971) and unweighted UV-B-radiation. Dose of unweighted and weighted UV-B-radiation during the entire experimental time of PAR + UV-A + UV-B exposure were $25.55 \mathrm{~kJ} \mathrm{~m}^{-2} 4 \mathrm{~h}^{-1}$ and $0.82 \mathrm{~kJ} \mathrm{~m}^{-2}$ $4 \mathrm{~h}^{-1}$, respectively. Different letters behind data represent statistically significant differences between light treatments

Condiciones de luz en los tratamientos experimentales medidos usando un espectroradiómetro UV/VIS (Ramses ACC, TriOS GmbH, Oldenburg, Alemania). Las radiaciones UV-B ponderadas fueron calculadas multiplicando el espectro de acción de la respuesta de daño generalizado en plantas de acuerdo a Caldwell (1971) y la radiación UV-B experimental.

Dosis de radiación UV-B experimentales (no ponderadas) y ponderadas durante el periodo de experimentación a exposiciones a PAR + UV-A + UV-B fueron $25,55 \mathrm{~kJ} \mathrm{~m}^{-2} 4 \mathrm{~h}^{-1}$ y $0,82 \mathrm{~kJ} \mathrm{~m}^{-2} 4 \mathrm{~h}^{-1}$, respectivamente. Diferentes letras representan diferencias estadísticamente significativas entre tratamientos de iluminación

\begin{tabular}{lcccc}
\hline Light treatment & PAR $\left(\mu\right.$ mol photons m $\left.{ }^{-2} \mathrm{~s}^{-1}\right)$ & $\mathrm{UV}-\mathrm{A}\left(\mathrm{W} \mathrm{m}^{-2}\right)$ & $\mathrm{UV}-\mathrm{B}\left(\mathrm{W} \mathrm{m}^{-2}\right)$ unweighted & $\mathrm{UV}_{-\mathrm{B}}\left(\mathrm{W} \mathrm{m}^{-2}\right)$ weighted \\
\hline PAR & $17.4 \pm 0.9^{\mathrm{a}}$ & $1.2 \pm 0.0^{\mathrm{a}}$ & $0.00 \pm 0.00^{\mathrm{a}}$ & $0.00 \pm 0.00^{\mathrm{a}}$ \\
PAR + UV-A & $16.0 \pm 0.9^{\mathrm{a}}$ & $9.8 \pm 0.4^{\mathrm{b}}$ & $0.16 \pm 0.00^{\mathrm{b}}$ & $0.00^{\mathrm{a}} 0.00^{\mathrm{a}}$ \\
PAR + UV-A + UV-B & $16.9 \pm 0.9^{\mathrm{a}}$ & $11.6 \pm 0.4^{\mathrm{c}}$ & $1.77 \pm 0.01^{\mathrm{c}}$ & $0.06 \pm 0.00^{\mathrm{b}}$ \\
\hline
\end{tabular}




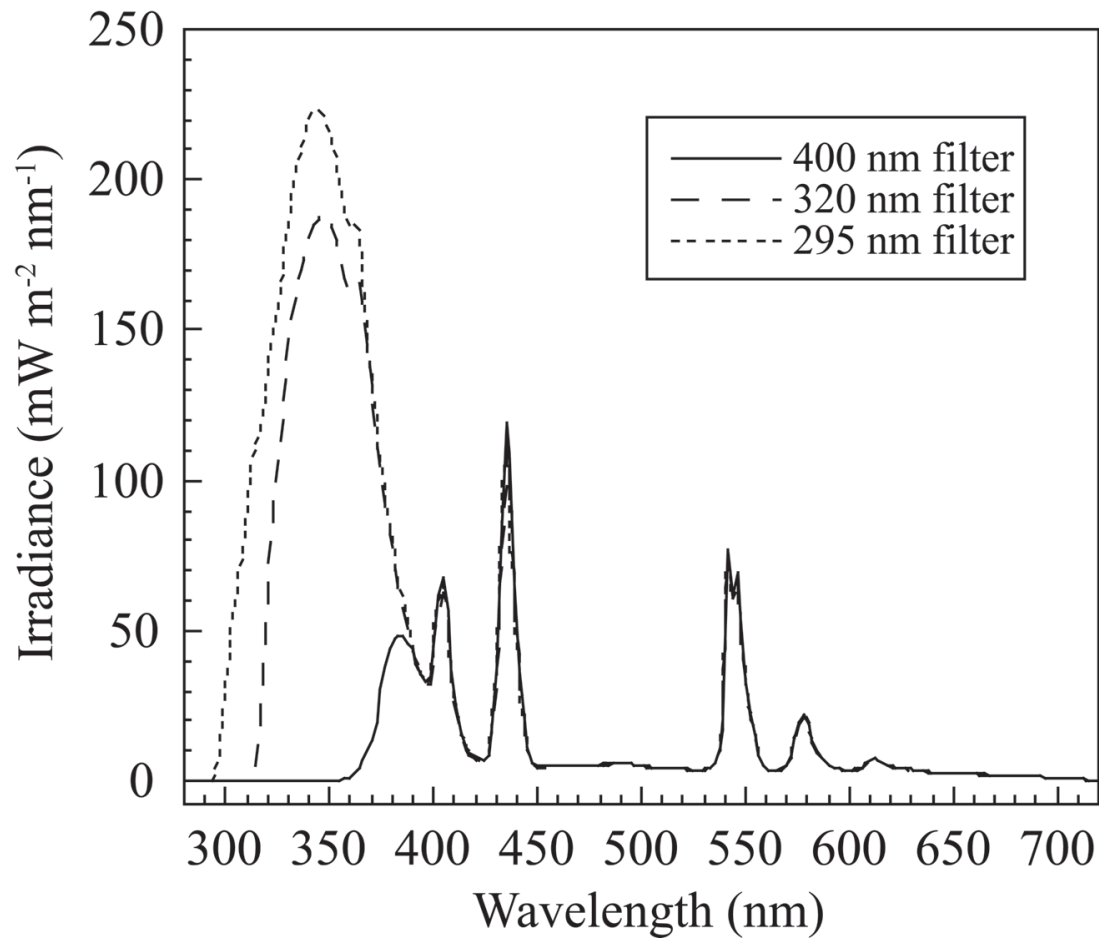

Fig. 2: Spectral composition of the experimental light regime exposed to the macroalgae. PAR alone (= control): solid line, PAR + UV-A: dashed line, PAR + UV-A + UV-B: dotted line.

Composición espectral del régimen de luz experimental al cual se expusieron las macroalgas. PAR solo (= control): línea sólida, PAR +UV-A: línea segmentada, PAR +UV-A + UV-B: línea punteada.

to simulate daily UV-B doses occurring both under ozone depletion in early spring (October) and under non depleted conditions in summertime caused by low a solar zenith angle over southernmost South America [around 31 ${ }^{\circ}$ in December, database of National Science Foundation UV Monitoring Network, USA (http://www.biospherical.com/nsf/)]. After UVexposure, algae were cultivated under low PAR intensities of $20 \mu \mathrm{mol}$ photons $\mathrm{m}^{-2} \mathrm{~s}^{-1}$ for recovery. Measurements of chlorophyll $a$ fluorescence were performed before $\left(\mathrm{t}_{0}\right)$, after two and $4 \mathrm{~h}$ of UV-exposure and after four and $24 \mathrm{~h}$ of recovery. The experiment performed with $P$. columbina was completed after $4 \mathrm{~h}$ of recovery; therefore data after $24 \mathrm{~h}$ of recovery are not available.

\section{Chlorophyll a fluorescence measurements}

Measurements of in vivo chlorophyll $a$ fluorescence were performed with a portable pulse amplitude modulated fluorometer PAM2100 (Walz GmbH, Effeltrich, Germany) according to the protocol of Hanelt (1998). Pieces of algal material were taken from Petri dishes and samples were inserted into custommade cuvettes filled with seawater at $8 \pm 1{ }^{\circ} \mathrm{C}$. The end of the fiber optic probe of the PAMfluorometer was mounted to the algal samples at a distance of $5 \mathrm{~mm}$. After the application of a $5 \mathrm{~s}$ far-red pulse, the brown and green algae were darkened for $5 \mathrm{~min}$. Measuring the red alga, a second short, red, actinic pulse was given after 5 min. of dark adaptation. Basal fluorescence, $\mathrm{F}_{0}$, was determined by using the measuring beam and maximal fluorescence, Fm, was induced after applying a saturation pulse. Photosynthetic efficiencies were calculated according to the equation of Schreiber et al. (1994).

$$
\frac{F v}{F m^{\prime}}=\frac{\left(F m^{\prime}-F_{t}\right)}{F m^{\prime}}
$$

The change of Fv/Fm over the experimental time was expressed as percentage of inhibition (\%) and calculated by the formula: 


$$
\text { Inhibition }=100-100 \cdot \frac{F v / F m_{U V}}{F v / F m_{\text {control }}}
$$

$\mathrm{Fv} / \mathrm{Fm}_{\mathrm{UV}}$ represents photosynthetic efficiency of samples exposed to PAR + UV-A and PAR + UV-A + UV-B. Fv/Fm control $_{\text {is }}$ photosynthetic efficiency of samples exposed under PAR alone.

Linear regression revealed as the best fit (y $\left.=\mathrm{mx}+\mathrm{n}, \mathrm{r}^{2} \geq 0.61\right)$ to determine the rates of inhibition of PSII $\left(\mathrm{m}_{\mathrm{inh}}\right)$ after $4 \mathrm{~h}$ of UVexposure (Fig. 8). Rates of recovery $\left(\mathrm{m}_{\mathrm{rec}}\right)$, however, were obtained by fitting data to an exponential function $\left(y=a \cdot e^{-b x}, r^{2} \geq 0.95\right)$.

Specimens were illuminated with continuous increasing actinic white light intensities (PPFD: 42-1,562 $\mu \mathrm{mol}$ photons $\mathrm{m}^{-2}$ $\left.\mathrm{s}^{-1}\right)$. Every $30 \mathrm{~s}$, the actinic light intensity was further increased after application of a saturation pulse to determine effective quantum yield of PSII ( $\left.\varphi_{\text {PSII }}\right)$ :

$$
\varphi_{P S I I}=\frac{F m^{\prime}-F_{t}}{F m^{\prime}}
$$

Calculation of relative electron transport rate (rel. ETR) was performed by multiplying the effective quantum yield of PSII by corresponding intensities of actinic white light $($ PPFD $=$ photosynthetically photon flux density) according to Schreiber et al. (1994):

$$
\text { rel. } E T R=\varphi_{P S I I} \bullet P P F D
$$

Then, relative ETR was plotted against PPFD of incident light and data points werefitted and calculated according to the model of Eilers \& Peeters (1988). Photosynthesis vs. irradiance curves (P-I curves) were used to estimate the photosynthetic activity by determination of maximal electron transport rate (ETRmax) according to Bischof et al. (1999) and light saturation point of photosynthesis $\left(\mathrm{I}_{\mathrm{k}}\right)$. Initial linear slopes $(\alpha)$ of P-I curves do not represent photosynthetic quantum efficiency because the amount of absorbed photons was not determined (Saroussi \& Beer 2007).

\section{Data treatment}

For controls (non-photoinhibited cultures exposed to PAR alone), $\mathrm{Fv} / \mathrm{Fm}$ ratios for $U$. intestinalis $(0.742 \pm 0.008$ r.u. $)$, A. utricularis
(0.744 \pm 0.003 r.u.), $P$. columbina (0.659 \pm 0.020 r.u. $),$ D. ligulata $(0.728 \pm 0.005$ r.u. $)$ and D. confervoides $(0.676 \pm 0.004$ r.u. $)$ were determined and remained constant during the whole experimental time. Mean values of respective $\mathrm{Fv} / \mathrm{Fm}$ values of controls were normalized to $100 \%$ and all the following values were calculated as a percentage of these. Statistical analyses were performed using JMP IN 5.1 (SAS Institute Inc., USA) following an arcsin-transformation of the data set. One-way analysis of variance (ANOVA) with repeated measurements and the Tukey-Kramer honestly significant difference (HSD) post-hoc test was performed in order to identify differences between treatments. A level of probability of $\mathrm{P}$ $\leq 0.05$ was used.

\section{RESULTS}

\section{P-I parameters of field-grown macroalgae un-} der non-stressful conditions

Initial linear slope of P-I curves $(\alpha)$ of all five species ranged from 0.47 to 0.80 ( $\mu \mathrm{mol}$ photons $\left.\mathrm{m}^{-2} \mathrm{~s}^{-1}\right)^{-1}(\mathrm{n}=6$ to 9$)$. The green alga $U$. intestinalis, the red macroalga $P$. columbina and the brown macroalgal species $A$. utricularis exhibited a steeper slope ranging from 0.78 to 0.80 ( $\mu$ mol photons $\left.\mathrm{m}^{-2} \mathrm{~s}^{-1}\right)^{-1}$ (Table 3). All these species were collected in the eulittoral (Table 1). In contrast, brown algal species, $D$. confervoides and $D$. ligulata, collected from the upper sublittoral had statistically lower initial $\alpha$-slopes of 0.47 and 0.55 ( $\mu$ mol photons $\mathrm{m}^{-2}$ $\left.\mathrm{s}^{-1}\right)^{-1}(\mathrm{n}=8$ and $\mathrm{n}=7)$, respectively.

The highest maximum relative electron transport rates (ETRmax) of $136.1 \pm 15.2$ r.u. (n $=9$ ) were measured in the green alga $U$. intestinalis and these were followed by significantly lower ETRmax of $98.6 \pm 18.6$ r.u. $(\mathrm{n}=8)$ obtained from $D$. confervoides. In other three species occurring in different tidal locations, ETRmax ranged from 59.1 to 74.8 r.u. $(\mathrm{n}=6$ or 7$)$.

$U$. intestinalis and $D$. confervoides exhibited the highest light saturation points of photosynthesis $\left(\mathrm{I}_{\mathrm{k}}\right): 174.3 \pm 23.4 \mu \mathrm{mol}$ photons $\mathrm{m}^{-2} \mathrm{~s}^{-1}$ and $215.0 \pm 54.0 \mu \mathrm{mol}$ photons $\mathrm{m}^{-2} \mathrm{~s}^{-1}(\mathrm{n}$ $=9$ and $\mathrm{n}=8)$, respectively. $\mathrm{I}_{\mathrm{k}}$-values of $P$. columbina $\left(99.3 \pm 21.3 \mu \mathrm{mol}\right.$ photons $\mathrm{m}^{-2} \mathrm{~s}^{-1} ; \mathrm{n}$ =6), A. utricularis $(80.4 \pm 33.0 \mu \mathrm{mol}$ photons 
$\left.\mathrm{m}^{-2} \mathrm{~s}^{-1}, \mathrm{n}=7\right)$ and D. ligulata $(115.9 \pm 11.2$ $\mu$ mol photons $\mathrm{m}^{-2} \mathrm{~s}^{-1}, \mathrm{n}=7$ ) were statistically lower than those of $U$. intestinalis and $D$. confervoides but not different among each other (Table 3).

\section{Photosynthetic efficiency under UV-exposure}

In all examined macroalgae, both incident UV$A$ and UV-B radiation caused a decrease of the photosynthetic efficiencies (Fv/Fm) and, thus, an increase of inhibition of PSII. However, exposure to low PAR intensities alone (= control) did not lead to a PSII inhibition. The UV-induced increase of PSII inhibition was already observed after two hours of exposure to UV-A and UV-B radiation. At that time, no statistical differences of inhibition were detected between both UV-treatments in all species with the exception of $D$. confervoides. Photosystem II of that species was inhibited up to $7 \%$ due to incident UV-A radiation and to $12 \%$ due to UV-B radiation (Fig. 3). After four hours, inhibition did not increase statistically despite its prolonged exposure to UV radiation. Therefore, Desmarestia confervoides exhibited pronounced differences of PSII inhibition between exposure to UV-A (7 \%) and UV-B radiation (16\%). Photosystem II of $U$. intestinalis, however, showed marked differences only after four hours because of increased PSII inhibition due to prolonged exposure to UV-B radiation. PSII was inhibited by UV-A radiation up to $16 \%$ and due to UVB-exposure to $25 \%$ (Fig. 4). In D. ligulata, inhibition increased by the factor of two from 7 $\%$ after two hours to $14 \%$ after four hours of UV-A-exposure. However, increase of inhibition from $12 \%$ after two hours to $26 \%$ after four of UV-B-exposure was not significant $(\mathrm{P}>0.05)$. Nevertheless, impinging UV-B radiation caused a statistically higher inhibition of PSII than UV-A radiation (Fig. 5). In $P$. columbina and A. utricularis, maximum degrees of inhibition were already reached after two hours under both UV-treatments. They did not further increase despite prolonged UVexposure of two hours additionally. In both species, neither UV-A radiation nor UV-B radiation caused significant differences of PSII inhibition at both times. UVA and UV-B radiation inhibited PSII to 5 to $13 \%$ in $P$. columbina, respectively (Fig. 6). In $A$. utricularis, exposure to UV-A and UV-B radiation lead to an inhibition of 15 to $26 \%$, respectively (Fig 7).

TABLE 3

Photosynthetic versus irradiance (P-I) parameters determined from relative maximal electron

transport rate (ETRmax) at continuously increasing actinic light intensities measured by pulseamplitude modulated (PAM) chlorophyll fluorescence. Tested field-grown macroalgal species were measured under unstressed conditions. Data were submitted to one-way ANOVA $(\mathrm{P}<0.05$, Tukey-

Kramer HSD test). Different letters denote statistical differences between each species for a corresponding P-I parameter

Parámetros de curvas fotosíntesis versus irradianza (P-I) determinados a partir de la tasa máxima de transporte de electrones (ETRmax) durante aumento continuo de intensidades de luz actínica usando fluorescencia de clorofilas de pulso/ amplitud modulada (PAM). Las mediciones de algas crecidas en ambiente natural se realizaron mientras estas no se encontraban sometidas a estrés solar. Los datos fueron tratados aplicando ANOVA de una vía $(\mathrm{P}<0,05$; prueba de TukeyKramer HSD). Diferentes letras denotan diferencias estadísticas entre cada especie para cada parámetro P-I

\begin{tabular}{|c|c|c|c|c|}
\hline Species & $\begin{array}{c}\text { Initial linear slope, } \\
\alpha\left[\left(\mu \mathrm{mol} \text { photons } \mathrm{m}^{-2} \mathrm{~s}^{-1}\right)^{-1}\right]\end{array}$ & Relative ETRmax(r.u.) & $\mathrm{I}_{\mathrm{k}}\left(\mu \mathrm{mol}\right.$ photons $\left.\mathrm{m}^{-2} \mathrm{~s}^{-1}\right)$ & $\mathrm{n}$ \\
\hline U. intestinalis & $0.79 \pm 0.06^{\mathrm{a}}$ & $136.1 \pm 15.2^{\mathrm{a}}$ & $174.3 \pm 23.4^{\mathrm{a}}$ & 9 \\
\hline P. columbina & $0.78 \pm 0.18^{a}$ & $74.8 \pm 7.2^{\mathrm{c}}$ & $99.3 \pm 21.3^{b}$ & 6 \\
\hline A. utricularis & $0.80 \pm 0.19^{a}$ & $59.1 \pm 11.2^{\mathrm{c}}$ & $80.4 \pm 33.0^{b}$ & 7 \\
\hline D. confervoides & $0.47 \pm 0.06^{b}$ & $98.6 \pm 18.6^{b}$ & $215.0 \pm 54.0^{\mathrm{a}}$ & 8 \\
\hline D. ligulata & $0.55 \pm 0.05^{b}$ & $63.2 \pm 6.3^{c}$ & $115.9 \pm 11.2^{b}$ & 7 \\
\hline
\end{tabular}




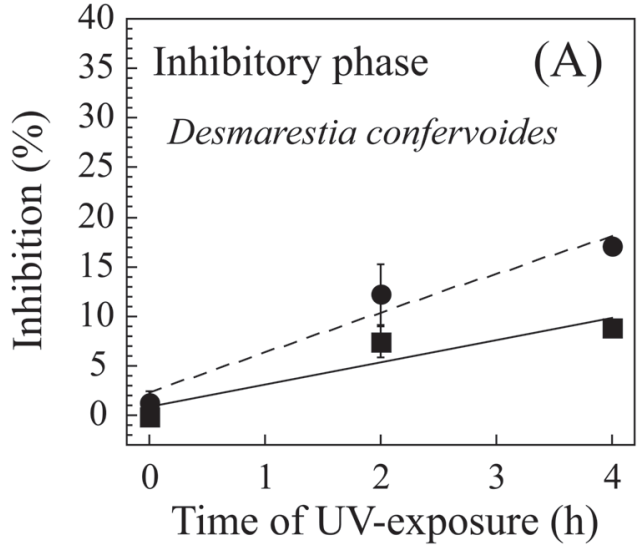

PA $\quad y=2.25 x+0.8333 \quad r^{2}=0.863$

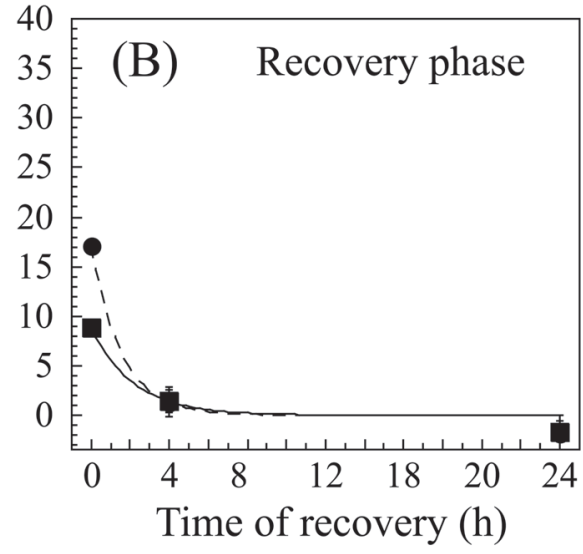

PA $\quad \mathrm{y}=55.357 \mathrm{e}^{(-0.45976 \mathrm{x})} \quad \mathrm{r}^{2}=0.950$

PAB $y=224.94 \mathrm{e}^{(-0.64418 x)} \quad \mathrm{r}^{2}=0.983$

Fig. 3: Desmarestia confervoides. Degree of photoinhibition (A) due to PAR + UV-A (PA: solid line) and PAR + UV-A + UV-B-exposure (PAB: dashed line) and its subsequent recovery (B) up to $24 \mathrm{~h}$ in dim PAR. Photoinhibition data were fitted to a linear regression $(\mathrm{y}=m \mathrm{x}+n)$, while data of recovery phases were adjusted to an exponential function $\left(\mathrm{y}=\mathrm{a} \cdot \mathrm{e}^{(-\mathrm{bx})}\right)$. Equations and coefficients of determination are shown for each phase.

Desmarestia confervoides. Grado de fotoinhibición (A) debido a la exposición a PAR + UV-A (PA: línea sólida) y PAR + UV-A +UV-B (PAB: línea segmentada) y su subsiguiente recuperación (B) a las $24 \mathrm{~h}$ de exposición en luz tenue. Las curvas de fotoinhibición fueron calculadas usando regresión lineal, mientras que las fases de recuperación fueron ajustadas a una función exponencial $\left(\mathrm{y}=\mathrm{a} \cdot \mathrm{e}^{(-\mathrm{bx})}\right)$. Las ecuaciones y coeficientes de determinación son indicadas para cada fase.

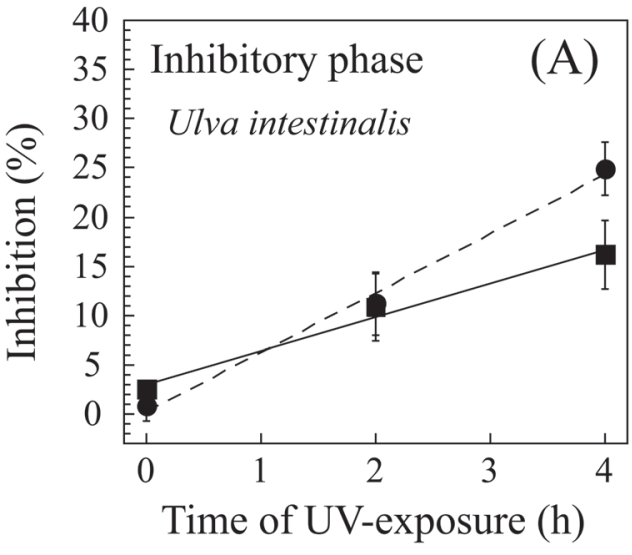

$\begin{array}{lll}\text { PA } & y=3.425 x+2.983 & r^{2}=0.985 \\ \text { PAB } & y=6.025 x+0.250 & r^{2}=0.994\end{array}$

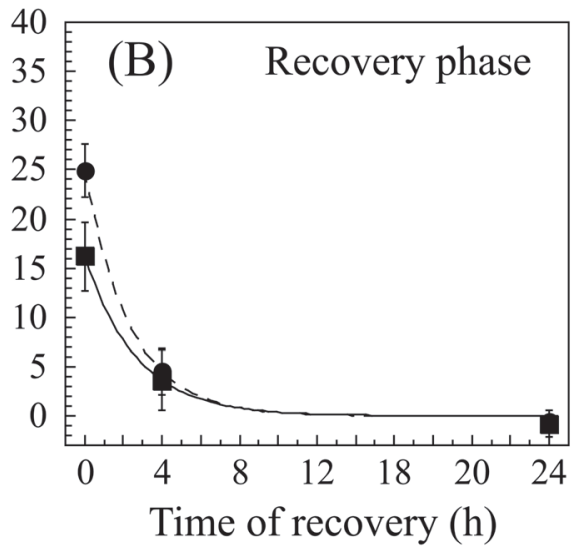

PA $\quad y=72.957 \mathrm{e}^{(-0.3763 \mathrm{x})} \quad \mathrm{r}^{2}=0.995$

PAB $y=137.800 \mathrm{e}^{(-0.4277 \mathrm{x})} \quad \mathrm{r}^{2}=0.999$

Fig. 4: Ulva intestinalis. Degree of photoinhibition (A) due to PAR + UV-A (= PA: solid line) and PAR + UV-A + UV-B-exposure (PAB: dashed line) and its subsequent recovery (B) up to 24 hours in $\operatorname{dim}$ PAR. Photoinhibition data were fitted to a linear regression $(\mathrm{y}=m \mathrm{x}+n)$, while data of recovery phases were adjusted to an exponential function $\left(y=a \cdot e^{(-b x)}\right)$. Equations and coefficients of determination are shown for each phase.

Ulva intestinalis. Grado de fotoinhibición (A) debido a la exposición a PAR + UV-A (PA: línea sólida) y PAR + UV-A + UV-B (PAB: línea segmentada) y su subsiguiente recuperación (B) a las 24 h de exposición en luz tenue. Las curvas de fotoinhibición fueron ajustadas a una regresión lineal, mientras que las fases de recuperación fueron ajustadas a una función exponencial $\left(\mathrm{y}=\mathrm{a} \cdot \mathrm{e}^{(-\mathrm{bx})}\right)$. Las ecuaciones y coeficientes de determinación son indicadas para cada fase. 

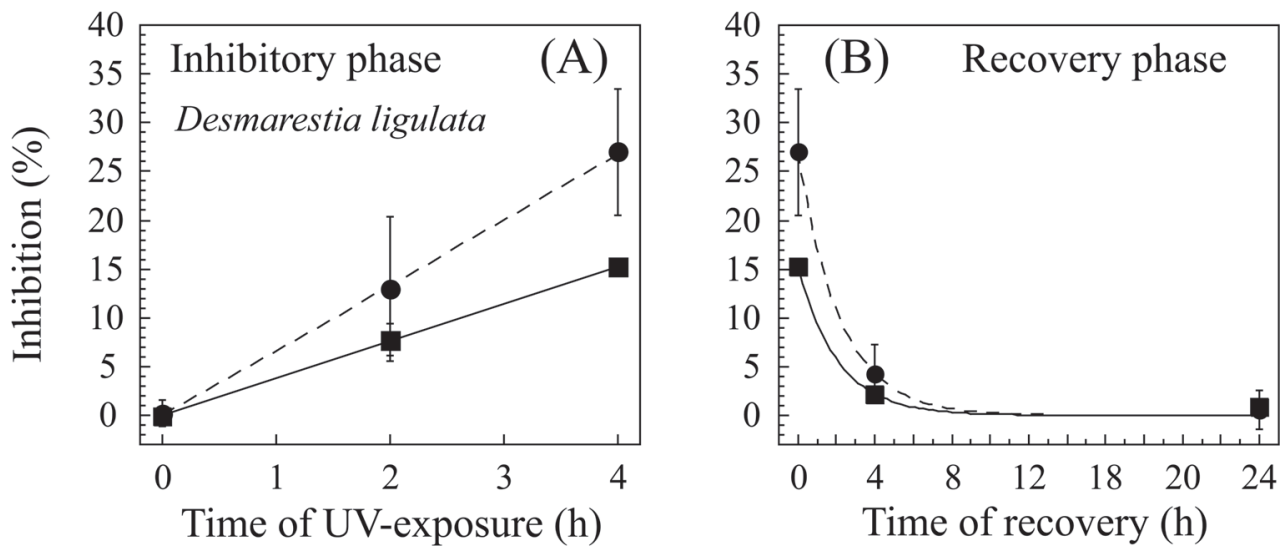

$$
\begin{array}{lll}
\text { PA } & y=3.825 x-0.05 & r^{2}=0.999 \\
\text { PAB } & y=6.7 x+2.4835 \times 10^{-9} & r^{2}=0.999
\end{array}
$$$$
\text { PA } \quad y=105.00 \mathrm{e}^{(-0.48317 \mathrm{x})} \quad \mathrm{r}^{2}=0.994
$$$$
\text { PAB } y=169.52 \mathrm{e}^{(-0.45928 x)} \quad \mathrm{r}^{2}=0.999
$$

Fig. 5: Desmarestia ligulata. Degree of photoinhibition (A) due to PAR + UV-A (PA: solid line) and PAR + UV-A + UV-B-exposure (PAB: dashed line) and its subsequent recovery (B) up to $24 \mathrm{~h}$ in $\operatorname{dim}$ PAR. Photoinhibition data were fitted to a linear regression $(\mathrm{y}=m \mathrm{x}+n)$, while data of recovery phases were adjusted to an exponential function $\left(y=a \cdot e^{(-b x)}\right)$. Equations and coefficients of determination are shown for each phase.

Desmarestia ligulata. Grado de fotoinhibición (A) debido a la exposición a PAR + UV-A (PA: línea sólida) y PAR + UV-A +UV-B (PAB: línea segmentada) y su subsiguiente recuperación (B) a las 24 h de exposición en luz tenue. Las curvas de fotoinhibición fueron ajustadas usando regresión lineal, mientras que las fases de recuperación fueron ajustadas a una función exponencial $\left(y=a \cdot e^{(-b x)}\right)$. Las ecuaciones y coeficientes de determinación son indicadas para cada fase.
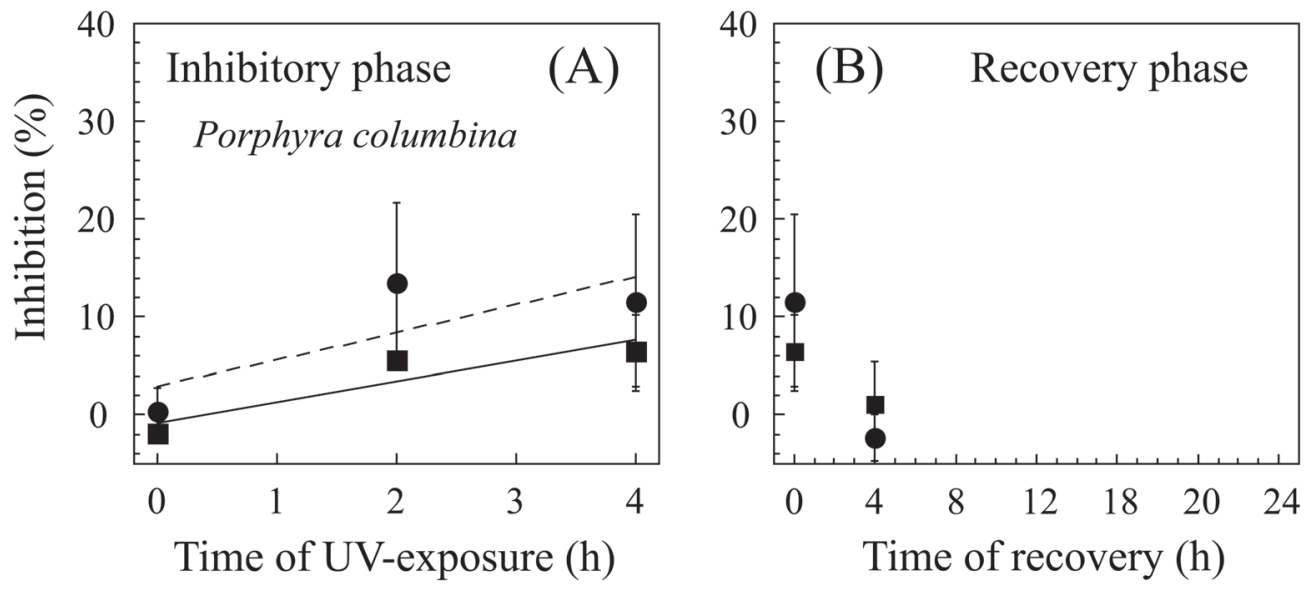

$$
\begin{array}{lll}
\text { PA } & y=2.1 x-0.8 & r^{2}=0.829 \\
\text { PAB } & y=2.8 x+2.8333 & r^{2}=0.617
\end{array}
$$

Fig. 6: Porphyra columbina. Degree of photoinhibition (A) due to PAR + UV-A (= PA: solid line) and PAR + UV-A + UV-B-exposure (PAB: dashed line) and its subsequent recovery (B, right). The experiment was cancelled after four hours of recovery; therefore, data of 24 hours of recovery are not available. Photoinhibition data were fitted to a linear regression $(\mathrm{y}=m \mathrm{x}+\mathrm{n})$. Equation and coefficient of determination is only shown for inhibitory phase.

Porphyra columbina. Grado de fotoinhibición (A) debido a la exposición a PAR + UV-A (PA: línea sólida) y PAR + UV-A + UV-B (PAB: línea segmentada) y su subsiguiente recuperación (B) a las 4 h de exposición en luz tenue. Las curvas de fotoinhibición fueron ajustadas a una regresión lineal. Las ecuaciones y coeficientes de determinación son indicados para la fase de inhibición. 


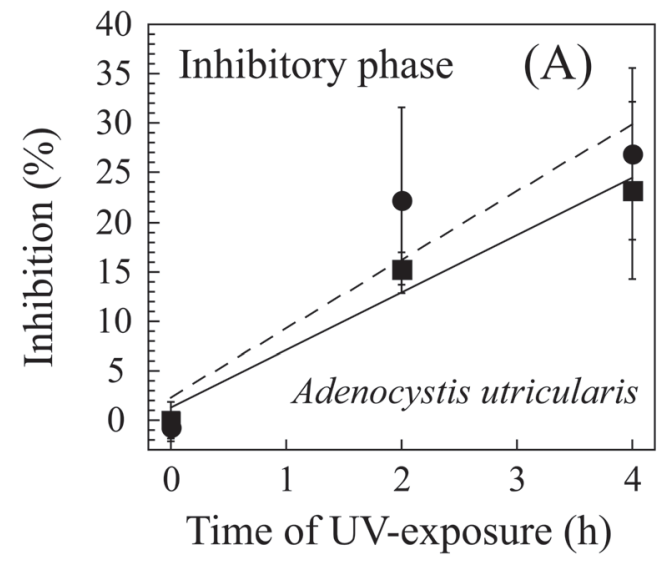

$\begin{array}{lll}\text { PA } & y=5.8 x+1.2333 & r^{2}=0.967 \\ \text { PAB } & y=6.9 x+2.3333 & r^{2}=0.873\end{array}$

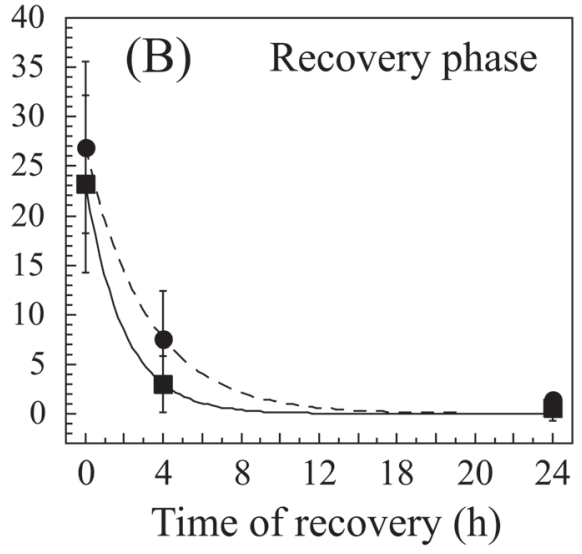

PA $\quad y=179.410 \mathrm{e}^{(-0.5114 x)} \quad \mathrm{r}^{2}=0.999$

PAB $y=94.998 \mathrm{e}^{(-0.31546 x)} \quad \mathrm{r}^{2}=0.995$

Fig. 7: Adenocystis utricularis. Degree of photoinhibition (A) due to PAR + UV-A (= PA: solid line) and PAR + UV-A + UV-B-exposure (PAB: dashed line) and its subsequent recovery (B) up to $24 \mathrm{~h}$ in dim PAR. Photoinhibition data were fitted to a linear regression $(\mathrm{y}=m \mathrm{x}+n)$, while data of recovery phases were adjusted to an exponential function $\left(\mathrm{y}=\mathrm{a} \cdot \mathrm{e}^{(-\mathrm{bx})}\right)$. Equations and coefficients of determination are shown for each phase.

Adenocystis utricularis. Grado de fotoinhibición (A) debido a la exposición a PAR + UV-A (PA: línea sólida) y PAR + UV-A +UV-B (PAB: línea segmentada) y su subsiguiente recuperación (B) a las 24 h de exposición en luz tenue. Las curvas de fotoinhibición fueron ajustadas usando regresión lineal, mientras que las fases de recuperación fueron ajustadas a una función exponencial $\left(\mathrm{y}=\mathrm{a} \cdot \mathrm{e}^{(-\mathrm{bx})}\right)$. Las ecuaciones y coeficientes de determinación son indicadas para cada fase.

Highest rates of inhibition $\left(\mathrm{m}_{\mathrm{inh}}\right)$ were detected in A. utricularis (UVA: $5.80 \pm 1.95$, UV-B: $6.91 \pm 1.91 ; \mathrm{n}=3$ ), U. intestinalis (UVA: $3.30 \pm 0.63$, UV-B: $6.08 \pm 0.88 ; \mathrm{n}=3$ ) and $D$. ligulata (UVA: $3.83 \pm 0.38$, UV-B: $6.67 \pm 1.53$; $\mathrm{n}=3$ ) exposed to both UV treatments (Fig. 8). The other two species ( $P$. columbina and $D$. confervoides) exhibited low inhibition rates of $2.17 \pm 0.58$ and $2.24 \pm 0.05$ (both $\mathrm{n}=3$ ) due to UV-A exposure and $2.75 \pm 1.64$ and $3.97 \pm 0.25$ (both $\mathrm{n}=3$ ) under UV-B radiation (Fig. 8).

After transfer to low PAR intensities close to $20 \mu \mathrm{mol}$ photons $\mathrm{m}^{-2} \mathrm{~s}^{-1}$, first inhibition of PSII decreased again quickly within four hours but, then, it slowed down within subsequent 20 hours in each species. This suggests a two stage recovery of PSII. After four hours in dim PAR, inhibition of PSII in $P$. columbina and $D$. confervoides did recover completely $(=0 \%$ of inhibition) (Fig. 3 and 6). Although degrees of inhibition were still approximately $5 \%$ in the other three species after four hours, they required 24 hours to recover completely. Specimens of A. utricularis exposed to PAR + UV-A + UV-B, however, recovered to $97 \%$ after 24 hours in comparison to control cultures. However, rates of recovery $\left(\mathrm{m}_{\mathrm{rec}}\right)$ were not statistically significant between species and UV-treatment (Fig. 9).

Photosynthesis versus irradiance $(P-I)$ curves of UV-exposed macroalgae

Comparisons of photosynthesis versus irradiance (P-I) curves after four hours of exposure to UV-A and UV-B radiation of all examined species are displayed in Fig. 10, 11 and 12. Maximal relative electron transport rates (ETRmax) of controls of the chlorophyte $U$. intestinalis were $151.6 \pm 8.1$ r.u. $(\mathrm{n}=3)$ but incident UV-A radiation significantly decreased relative ETRmax down to $121.6 \pm 9.5$ r.u. $(\mathrm{n}=$ 3) (Fig. 10A). Exposure of $U$. intestinalis to UV-B radiation also reduced ETRmax to 130.6 \pm 11.4 r.u. $(\mathrm{n}=3)$ but this reduction, however, was not statistically different to that of controls. In contrast, ETRmax of other four species (P. columbina (Fig. 10B), A. utricularis (Fig. 11), D. confervoides (Fig. 12A) and D. ligulata) did not change statistically due to exposure neither to PAR + UV-A nor to PAR + UV-A + UV-B. 


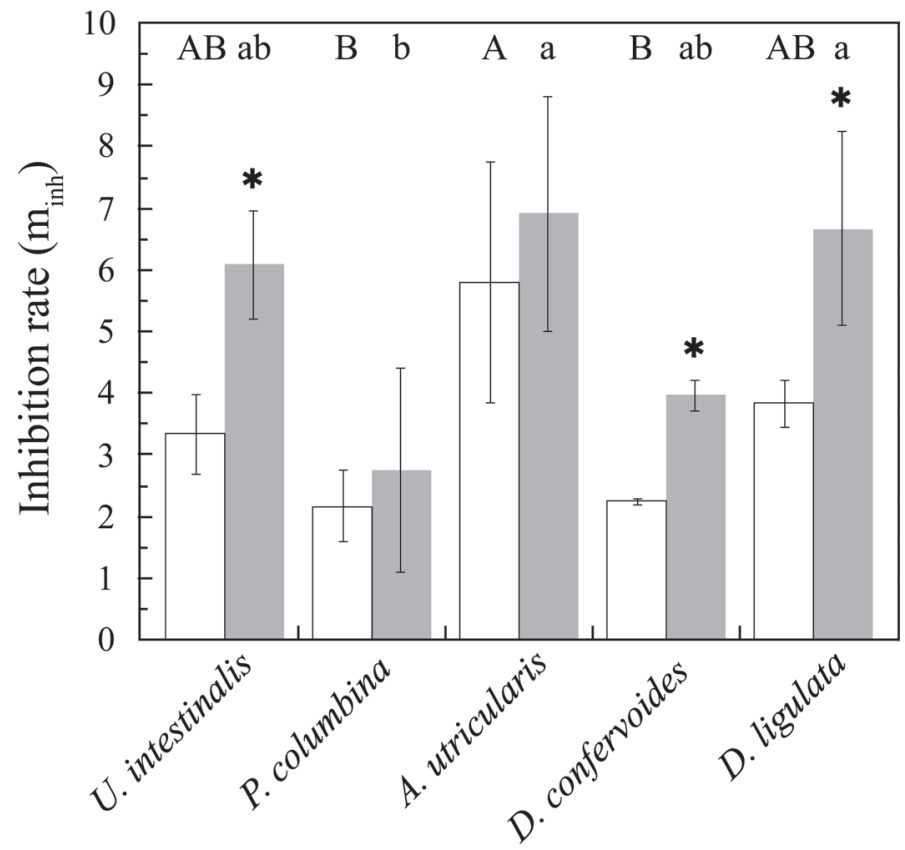

Fig. 8: Rates of inhibition of $\mathrm{Fv} / \mathrm{Fm}\left(\mathrm{m}_{\text {inh }}\right)$ in five macroalgal species after a four hours exposure to PAR + UV-A (white columns) and PAR + UV-A + UV-B radiation (grey columns). Big and small letters represent statistical differences of inhibition rate between all species exposed either UV-A or UV-B radiation. Asterisks represent statistical differences between UV-A and UV-B effects within a species.

Tasas de la fase de inhibición $\left(\mathrm{m}_{\mathrm{inh}}\right)$ de cinco especies de macroalgas luego de cuatro horas de exposición a radiación PAR + UV-A (columnas blancas) y PAR + UV-A + UV-B (columnas grises). Letras grandes y pequeñas representan diferencias estadísticas en las tasas de inhibición entre todas las especies expuestas ya sea a UV-A o UV-B. Los asteriscos denotan diferencias estadísticas entre los efectos de UV-A y UVB dentro de cada especie.

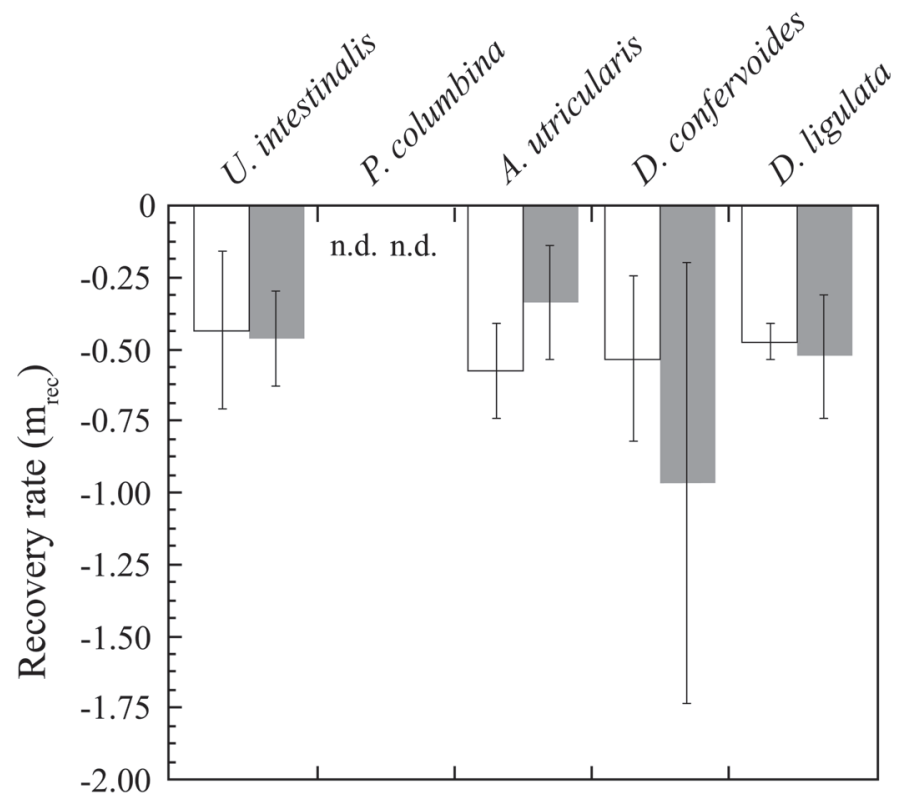

Fig. 9: Rates of recovery $\left(\mathrm{m}_{\mathrm{rec}}\right)$ of five macroalgal species which were previously exposure to PAR + UV-A (white columns) and PAR + UV-A + UV-B radiation (grey columns). N.d. indicates no data after $24 \mathrm{~h}$ of recovery.

Tasas de la fase de recuperación $\left(\mathrm{m}_{\mathrm{rec}}\right)$ de cinco especies de macroalgas que fueron previamente expuestas a radiación PAR + UV-A (columnas blancas) y PAR + UV-A + UV-B (columnas grises). 

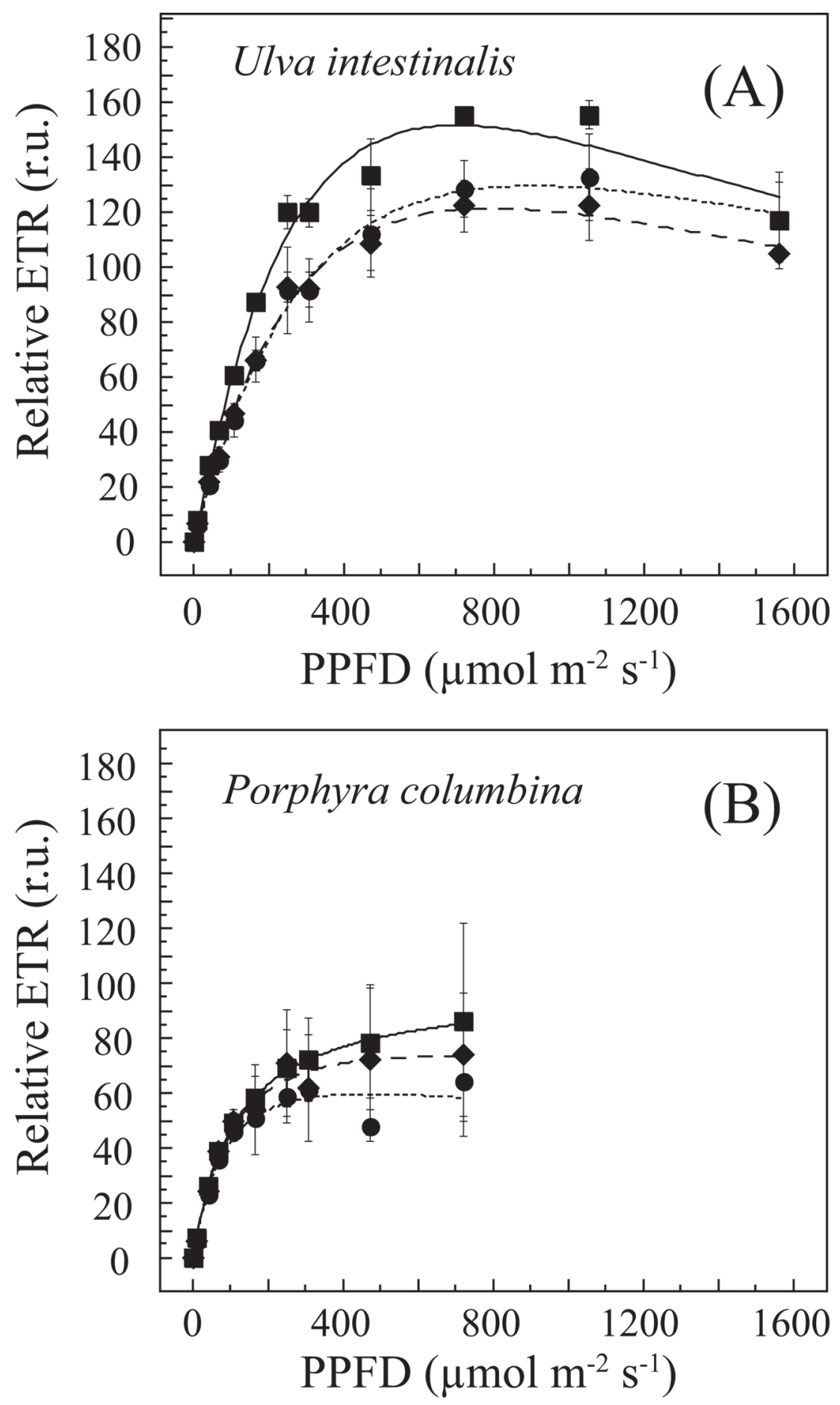

Fig. 10: Light curves of the green alga Ulva intestinalis (A) and the red macroalga Porphyra columbina (B) after four hours of exposure to low PAR (solid line), PAR + UV-A (dashed line) and $\mathrm{PAR}+\mathrm{UV}-\mathrm{A}+\mathrm{UV}-\mathrm{B}$ radiation (dotted line).

Curvas de luz del alga verde Ulva intestinalis (A) y la macroalga roja Porphyra columbina (B) luego de cuatro horas de exposición a baja radiación PAR (línea sólida), PAR + UV-A (línea segmentada) y PAR + UV-A + UV-B (línea punteada). 


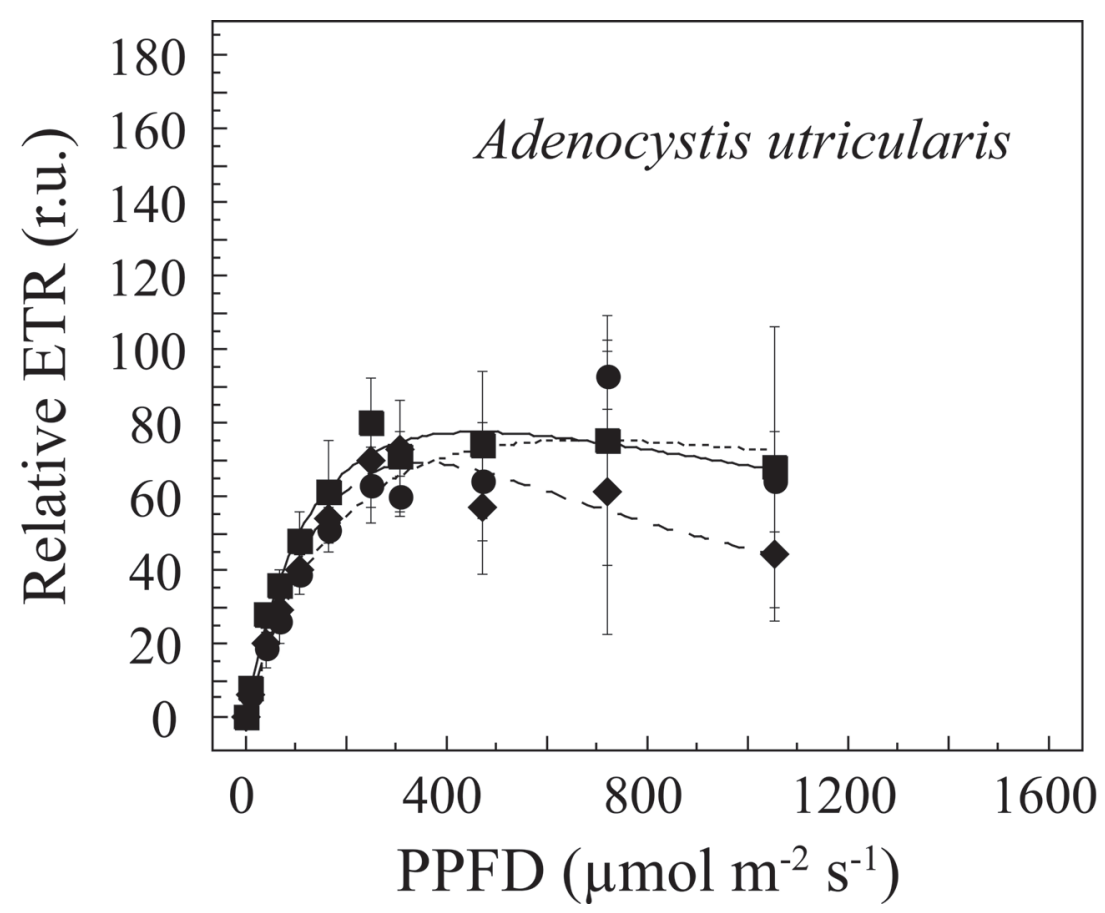

Fig. 11: Light curves of the brown alga Adenocystis utricularis after four hours of exposure to low PAR (solid line), PAR + UV-A (dashed line) and PAR + UV-A + UV-B radiation (dotted line).

Curvas de luz del alga parda Adenocystis utricularis después de cuatro horas de exposición a baja radiación PAR (línea sólida), PAR + UV-A (línea segmentada) y PAR + UV-A + UV-B (línea punteada).

\section{DISCUSSION}

Here, for the first time, we conducted studies on the photosynthetic performance of five fieldgrown macroalgal species collected at the Strait of Magellan in southernmost Chile with respect to photoadaptation to their vertical pattern of distribution and their acclimation to ultraviolet radiation. All examined species exhibited a fast acclimation to both UV-A and UV-B radiation as indicated by the fast return of decreased $\mathrm{Fv} /$ Fm to their initial photosynthetic efficiencies. Such high recovery rates of inhibited PSII were shown in various cold-temperate and polar macroalgae inhabiting the eulittoral and upper sublittoral in opposition to macroalgae from deeper growth sites (lower sublittoral) or the subcanopy exhibiting slower proceeding recoveries (Dring et al. 1996, Bischof et al. 1998). Down-regulation of photosynthetic efficiencies as a regulatory mechanism of photoprotection, rather than damage, is assumed due to fast kinetics of recovery after UV-exposure.

\section{Photoadaptive characteristics of algae}

P-I parameters of collected field-grown macroalgae (cultivated for 1-2 weeks in the laboratory under non-stressful conditions) give information about the state of photoadaptation, which is considered to be genetically fixed (reviewed by Bischof et al. 2006).

The results of rel. ETR suggest that photosynthetic performance is rather speciesspecific than a function of tidal position on the shore. A general pattern of ETRmax between species from the eulittoral and the upper sublittoral was absent. Studies of Gómez et al. (2004) confirm this finding as no correlation between ETRmax and position on the shore investigating 18 intertidal macroalgal species from the Chilean coast at Niebla $\left(41^{\circ} \mathrm{S}\right.$, near Valdivia) was found. These authors also showed that $U$. intestinalis had higher photosynthetic capacities than $P$. columbina and D. ligulata. This is consistent with this study. The results suggest that thallus morphology plays an important role influencing 

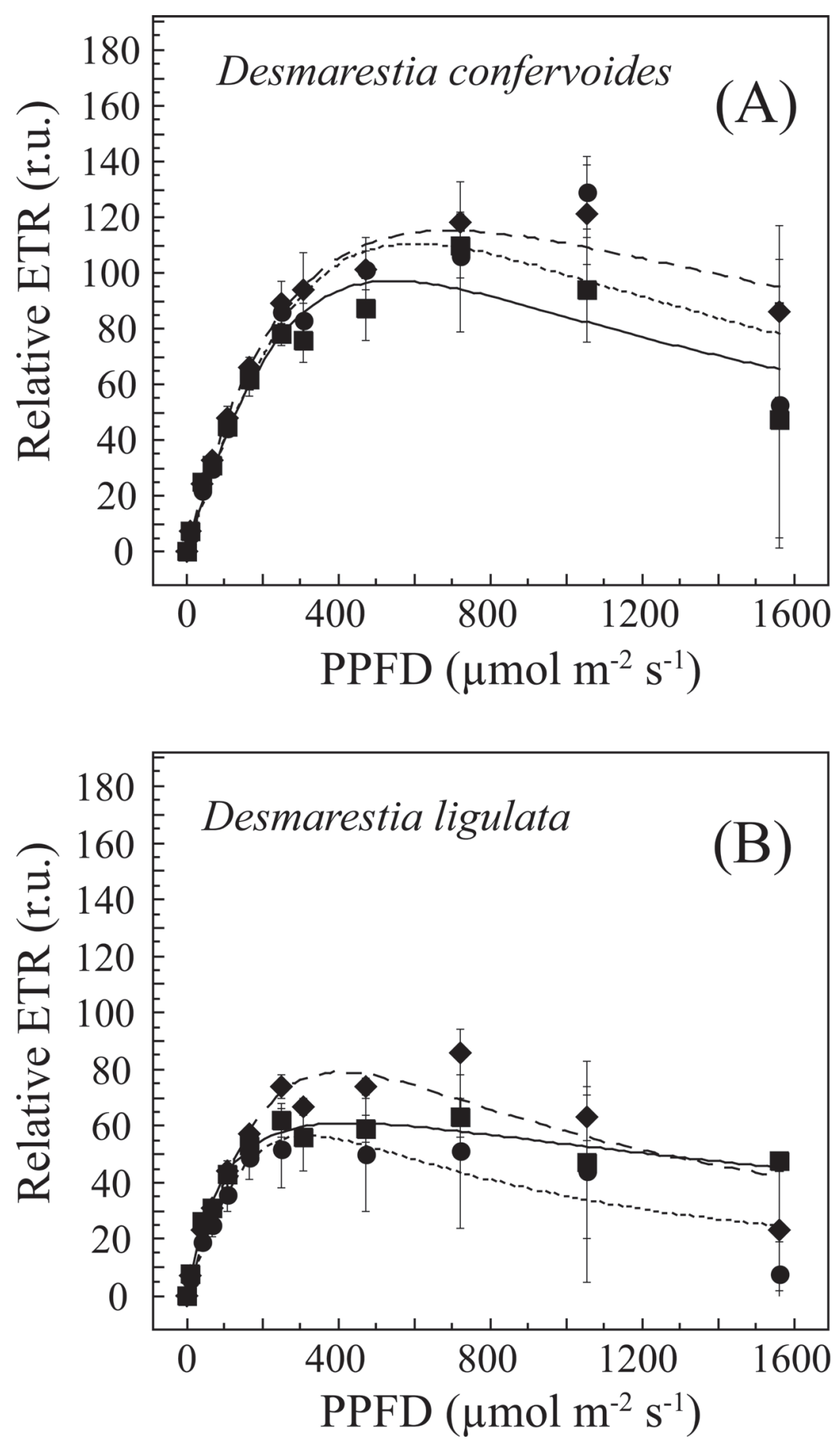

Fig. 12: Light curves of the brown macroalgal species Desmarestia confervoides (A) and Desmarestia ligulata (B) after four hours of exposure to low PAR (solid line), PAR + UV-A (dashed line) and PAR + UV-A + UV-B radiation (dotted line).

Curvas de luz de las especies de macroalga parda Desmarestia confervoides (A) y Desmarestia ligulata (B) después de cuatro horas de exposición a bajo radiación PAR(línea sólida), PAR + UV-A (línea segmentada) y PAR +UV-A + UV-B (línea punteada). 
photosynthetic capacity. Ulva intestinalis consists of a sheet-like but tubular thallus with a high content of chlorophyll a (Gómez et al. 2004). This thallus morph has a high surfaceto-volume ratio with almost exclusively photosynthetic cells (Weykam et al. 1996). Thus, $U$. intestinalis may be classified into a group with high photosynthetic rates according to the morpho-functional model described by Littler \& Arnold (1982). On the other hand, Johansson \& Snoeijs (2002) found that photosynthetic capacity (based on oxygen evolution and normalized to biomass) depends on thallus morphology: thinner and filamentous species had higher rates than coarser and thicker species. Similarly, Poole \& Raven (1997) outlined that most of species of the former genus Enteromorpha including $E$. intestinalis (now Ulva intestinalis) have high photosynthetic capacities. In our study, the lower photosynthetic capacity (Table 3) measured in A. utricularis and D. ligulata, which exhibit saccate or leathery morphology, respectively, are associated to less chlorophyll $a$, a lower surface-to-volume ratio and a great proportion of structural tissues (Weykam et al. 1996). The brown alga $D$. confervoides takes an intermediate position probably because of its terete and branched thallus morphology.

The light saturation point of photosynthesis $\left(\mathrm{I}_{\mathrm{k}}\right)$ is regarded as an indicator of the photoadaptive status of macroalgae with respect to their position in the littoral zone. For macroalgae from polar and Chilean coldtemperate waters, $\mathrm{I}_{\mathrm{k}}$-values are higher in species occurring in the eulittoral and the upper sublittoral than those determined in seaweeds growing below $10 \mathrm{~m}$ water depth (reviewed by Wiencke et al. 2007, Gómez et al. 2004). Thus, macroalgae from the midlittoral are better adapted to strong irradiances than species from the sublittoral. Such a clear general pattern could not be confirmed in this study. One reason might be the small number of species used in this study or alternatively, that all examined macroalgae inhabited shallow sites. Apparently, the studied algae are exposed to high irradiance conditions in summer and may be regarded as moderate sun-adapted organisms, irrespective of their position on the shore. For example, the eulittoral $U$. intestinalis and the upper sublittoral $D$. confervoides exhibited ranges of $\mathrm{I}_{\mathrm{k}}$ comparable. Depending on the biogeographic region, $\mathrm{I}_{\mathrm{k}}$ values 50 and $400 \mu \mathrm{mol} \mathrm{m} \mathrm{m}^{-2} \mathrm{~s}^{-1}$ indicate firstly sun-adapted characteristics and secondly that species are capable to cope with strong solar irradiance conditions by dynamic photoinhibition (Poole \& Raven 1997, Gómez et al. 2004, Hanelt et al. 1994). In contrast, only species occurring in deeper waters are characterized as shadeadapted (reviewed by Wiencke et al. 2007).

\section{Acclimation to $U V$-radiation}

Photosynthetic efficiencies were directly affected by incident UV radiation in all examined macroalgae collected in the tidal zone of the Strait of Magellan. The ratio of Fv/ $\mathrm{Fm}$ is an important and sensitive parameter to assess the physiological state of algae and plants exposed to environmental stress (Krause \& Weis 1991). UV-B-radiation leads to a stronger inhibition of PSII because of the higher energy content of UV-B waveband in comparison to UV-A waveband. In contrast to changes of $\mathrm{Fv} / \mathrm{Fm}$ during $\mathrm{UV}$-exposure, there was only a small impact of incident UVradiation on photosynthetic capacities, hence, $\mathrm{Fv} / \mathrm{Fm}$ is revealed as a more sensitive parameter for evaluation of UV-susceptibility of macroalgae than fluorescence-based P-I curves determined. This is in line with other studies performed on UV-mediated stress on brown and red macroalgae (Dring et al. 1996, Bischof et al. 1999). This suggests that the capture of light energy by the light harvesting complexes and energy transfer efficiency from the light harvesting complexes (LHC) to PSII of macroalgae might be more affected (Clendennen et al. 1996) than the photosynthetic reaction centers of PSII which may still remain active (Hanelt et al. 1997, Bischof et al. 1999).

Many studies have been undertaken to reveal correlations between susceptibility or tolerance of macroalgae to UV-radiation and their vertical distribution (reviewed by Bischof et al. 2006). Gómez et al. (2004) demonstrated that UV-tolerance of 18 intertidal macroalgae from Chile is rather related to metabolic adjustments than to morpho-functional groups or to vertical distribution. In our study, neither the morphology of macroalgal thalli nor the tidal distribution of examined species could be correlated to the extent of photoinhibition 
during UV-exposure or rate of recovery $\left(\mathrm{m}_{\mathrm{rec}}\right)$ in $\operatorname{dim}$ PAR. The ability of recovery in dim PAR is regarded as an important parameter for evaluation of UV-susceptibility (Hanelt et al. 1997, Bischof et al. 1999). Despite PAR is important for repair, the results show that the macroalgae recovered after UVR exposures, meaning that low PAR intensities used in this study, despite unrealistic, did not impair repair significantly. The rate of recovery was found to be independent on the extent of UV-induced photoinhibition and suggests that adverse effects of UV radiation on PSII were absent. Hence, this is a hint that acclimation of surveyed Patagonian macroalgae to UVradiation is based on species-specific adjustments of metabolism and photoprotective strategies. Furthermore, they exhibited a high acclimation potential to UV radiation regardless to their position on the shore.

\section{Porphyra columbina}

Porphyra columbina seems to be a very well acclimated species to enhanced UV radiation indicated by the low increase of inhibition of PSII, its complete recovery already after $4 \mathrm{~h}$ and unaffected P-I curves.

Porphyra umbilicalis from the upper eulittoral $(0 \mathrm{~m})$ of the Island of Helgoland (Germany) revealed no reduction of $\mathrm{Fv} / \mathrm{Fm}$ even after $96 \mathrm{~h}$ of UV-exposure (Dring et al. 1996). The high UV tolerance determined in several species of Porphyra is certainly due to the high content of UV-absorbing mycosporinelike amino acids (Karsten et al. 1998, Hoyer et al. 2003, Huovinen et al. 2004).

\section{Ulva intestinalis}

The green macroalga $U$. intestinalis exhibited a reduction of $\mathrm{Fv} / \mathrm{Fm}$ followed by a fast recovery completed within $24 \mathrm{~h}$. This indicates a transient and rapidly reversible down-regulation of photosynthetic activity. Down-regulation of the photosynthetic apparatus was interpreted by Russell et al. (1995) as a photoprotective strategy primarily developed to dissipate excess PAR energy, which might be also active as a response to ultraviolet radiation. A small distinct increase of PSII inhibition and a fast subsequent recovery were also reported of the same species from the Northern and Southern hemisphere exposed to artificial and solar radiation (Cordi et al. 1997, Gómez et al. 2004, Huovinen et al. 2006). Furthermore, a decrease of ETRmax after four hours of UV-A-exposure and its subsequent complete recovery after four hours (not shown) suggests that UV-A-radiation did not cause serious detrimental effects on the photosynthetic and enzymatic apparatus of the Calvin-Benson cycle.

UV-stress experiments conducted by Gómez et al. (2004) and Huovinen et al. (2006) using specimens of $U$. intestinalis occurring in the upper midlittoral near Valdivia (Chile) showed a less pronounced photoinhibition of approximately $10 \%$ and lower. The authors concluded that this species seems to be less susceptible to UV-radiation because of possibly highly efficient physiological acclimation to prevailing UV-conditions. This is in line with earlier studies by Cordi et al. (1997) who deduced a development of protection mechanism against UV-B-radiation.

Furthermore, in tide pools at the Strait of Magellan (R. Rautenberger, personal observation), U. intestinalis is protected against desiccation and its impairments on photosynthesis. Additionally, rising temperatures of the water of tide pools caused by heating of incident solar radiation might protect photosynthesis of $U$. intestinalis against UV-radiation, e.g., by more efficiently operating photoprotective mechanisms. This was shown for two Ulva species from southernmost Chile and the Antarctic region (Rautenberger \& Bischof 2006). Furthermore, low fluctuations of seasonal photoinhibitory response to ultraviolet radiation reflect a good adaptation to ambient irradiance conditions (Huovinen et al. 2006), which may be operating in Patagonian assemblages of $U$. intestinalis.

\section{Adenocystis utricularis}

Results of the brown alga $A$. utricularis suggest that this species was also well acclimated to UV-radiation possibly by regulatory mechanisms. Inhibition of PSII after four hours of UV-exposure was one of the highest compared to the other species. Subsequent (fast) recovery of photosynthetic activity and unaffected photosynthetic capacities after four hours of UV-exposure seems to indicate that photosynthesis was rather down regulated than 
damaged. Rautenberger \& Bischof (2008) also reported such a fast reversible photoinhibition in Antarctic members of this species. Hanelt et al. (1994) concluded from their fieldexperiments of diurnal changing solar irradiance in the Antarctic that A. utricularis is able to cope with strong radiation stress (including UV-radiation) in virtue of its ability for dynamic photoinhibition, which acts as a photoprotection mechanism (reviewed by Wiencke et al. 2007). Although these findings refer to Antarctic individuals, photosynthesis of Patagonian individuals of A. utricularis might also be protected by a rapidly reversible photoinhibition without further damage of the photosynthetic apparatus. During low tide, $A$. utricularis is exposed to arising ultraviolet radiation, which is accompanied by desiccation of algae. Apparently, photosynthesis could be additionally protected by the special thallus morphology of A. utricularis. Internal water reservoir inside the saccate thallus keeps it moistened and, thus, it avoids its desiccation (Hanelt et al. 1994).

\section{Desmarestia confervoides and D. ligulata}

Apparently, photosynthesis of $D$. confervoides and D. ligulata collected from the upper sublittoral was also transiently down regulated as shown for the midlittoral species. Nevertheless, the acclimation potential of both species from the same genus and the same tidal position was different and supports the idea of a species-specific phenomenon. Besides metabolic adjustments, UV-sunscreen substances may contribute to protect against UV-radiation. For example, Fairhead et al. (2005) have found phlorotannins, a type of phenolic compounds, in two Antarctic endemic species of Desmarestia (D. anceps and $D$. menziesii) but they could not provide evidence for their role in UV-protection (Fairhead et al. 2006). Overall, the laboratory experiment was designed to simulate weighted daily UV-B doses according to Caldwell (1971) occurring under ozone depletion in austral springtime and summer irradiance conditions over the southernmost South America in 2004 and 2005, respectively (database from National Science Foundation UV Monitory Network).

In conclusion, our results suggest that adult sporophytes of macroalgal species growing in the intertidal zone of the Strait of Magellan, in virtue of their ability for photoacclimation, are capable of coping with these UV-B doses. Here, a rapid and transient down regulation of photosynthesis seems to be the main mechanism under suddenly increasing UV levels. However, other adverse effects of enhanced UV-radiation, e.g., on small developmental stages of macroalgal species like spores and gametophytes may not be ruled out (Mansilla et al. 2006, Wiencke et al. 2007) and, therefore, further studies are needed.

\section{ACKNOWLEDGEMENTS}

The authors thank the Alfred Wegener Institute for Polar and Marine Research (Bremerhaven, Germany) for financial support to work in Punta Arenas. Further funding was provided by the Deutsche Forschungsgemeinschaft (BI 772/ 2-1,2) and the Helmholtz-Gemeinschaft deutscher Forschungszentren (VH-NG-059). The collaboration of Nelson Navarro and Mauricio Palacios (both Universidad de Magallanes in Punta Arenas) during collecting algal material and laboratory work is gratefully acknowledged.

\section{LITERATURE CITED}

BISCHOF K, D HANELT \& C WIENCKE (1998) UVradiation can affect depth-zonation of Antarctic macroalgae. Marine Biology 131: 597-605.

BISCHOF K, D HANELT \& C WIENCKE (1999) Acclimation of maximal quantum yield of photosynthesis in the brown alga Alaria esculenta under high light and UV radiation. Plant Biology 1 : 435-444.

BISCHOF K, I GÓMEZ, M MOLIS, D HANELT, U KARSTEN, U LÜDER, MY ROLEDA, K ZACHER \& C WIENCKE (2006) Ultraviolet radiation shapes seaweed communities. Reviews in Environmental Science and Biotechnology 5: 141-166.

CALDWELL MM (1971) Solar UV radiation and the growth and development of higher plants. In: Giese AC (ed) Photophysiology. Current topics in photobiology and photochemistry: 131-177. Academic Press, New York, New York, USA.

CASICCIA C, VWJH KIRCHHOFF \& A TORRES (2003) Simultaneous measurements of ozone and ultraviolet radiation: Spring 2000, Punta Arenas, Chile. Atmospheric Environment 37: 383-389.

CLENDENNEN SK, RC ZIMMERMAN, DA POWERS \& RS ALBERTE (1996) Photosynthetic response of the giant kelp Macrocystis pyrifera (Phaeophyceae) to ultraviolet radiation. Journal of Phycology 32 : 614-620. 
CORDI B, MH DEPLEDGE, DN PRICE, LF SALTER \& ME DONKIN (1997) Evaluation of chlorophyll fluorescence, in vivo spectrophotometric pigment absorption and ion leakage as biomarkers of UVB exposure in marine macroalgae. Marine Biology 130: 41-49.

DRING MJ, A WAGNER, J BOESKOV \& K LÜNING (1996) Sensitivity of intertidal and subtidal red algae to UVA and UVB radiation, as monitored by chlorophyll fluorescence measurements: Influence of collection depth and season, and length of irradiation. European Journal of Phycology 31: 293302.

EILERS PHC \& JCH PEETERS (1988) A model for the relationship between light intensity and the rate of photosynthesis in phytoplankton. Ecological Modelling 42: 199-215.

FARMAN JC, BG GARDINER \& JD SHANKLIN (1985) Large losses of total ozone in Antarctica reveal seasonal ClOx /NOx interaction. Nature 315: $207-$ 210.

FAIRHEAD VA, CD AMSLER, JB MCCLINTOCK \& BJ BAKER (2005) Variation in phlorotannin content within two species of brown macroalgae (Desmarestia anceps and D. menziesii) from the western Antarctic Peninsula. Polar Biology 28: 680686.

FAIRHEAD VA, CD AMSLER, JB MCCLINTOCK \& BJ BAKER (2006) Lack of defense or phlorotannin induction by UV radiation or mesograzers in Desmarestia anceps and D. menziesii (Phaeophyceae). Journal of Phycology 42: 11741183.

GÓMEZ I, F LÓPEZ-FIGUEROA, N ULLOA, V MORALES, C LOVENGREEN, P HUOVINEN \& S HESS (2004) Patterns of photosynthesis in 18 species of intertidal macroalgae from southern Chile. Marine Ecology Progress Series 270: 103116.

HÄDER DP, HD KUMAR, RC SMITH \& RC WORREST (2007) Effects of solar UV radiation on aquatic ecosystems and interactions with climate change. Photochemical \& Photobiological Sciences 6: 267 285.

HANELT D (1998) Capability of dynamic photoinhibition in Arctic macroalgae is related to their depth distribution. Marine Biology 131: 361-369.

HANELT D, MJ JARAMILLO, W NULTSCH, S SENGER \& R WESTERMEIER (1994) Photoinhibition as a regulative mechanism of photosynthesis in marine algae of Antarctica. Serie Científica del Instituto Antártico Chileno 44 (Chile): 67-77.

HANELT D, C WIENCKE \& W NULTSCH (1997) Influence of UV radiation on the photosynthesis of Arctic macroalgae in the field. Journal of Photochemistry and Photobiology B Biology 38: 40-47.

HOYER K, U KARSTEN \& C WIENCKE (2003) Inventory of UV-absorbing mycosporine-like amino acids in polar macroalgae and factors controlling their content. In: Huiskes AHL, WWC Gieskes, J Rozema, RML Schorno, SM van der Vies \& WJ Wolff (eds)Antarctic biology in a global contaxt: 56-62. Backhuys Publishers, Leiden, The Netherlands

HUOVINEN P, I GÓMEZ, FL FIGUEROA, U ULLOA, V MORALES \& C LOVENGREEN (2004) Absorbing mycosporine-like amino acids in red macroalgae from Chile. Botanica Marina 47: 21-29.

HUOVINEN P, I GÓMEZ \& C LOVENGREEN (2006) A five-year study of solar ultraviolet radiation in southern Chile $\left(39^{\circ} \mathrm{S}\right)$ : Potential impact on physiology of coastal marine algae? Photochemistry and Photobiology 82: 515-522.

JOHANSSON G \& P SNOEIJS (2002) Macroalgal photosynthetic responses to light in relation to thallus morphology and depth zonation. Marine Ecology Progress Series 244: 63-72.

KARSTEN U, T SAWALL, D HANELT, K BISCHOF, LF FIGUEROA, A FLORES-MOYA \& C WIENCKE (1998) An inventory of UV-absorbing mycosporinelike amino acids in macroalgae from polar to warmtemperate regions. Botanica Marina 41: 443453.

KARSTEN U, K BISCHOF, D HANELT, H TÜG \& C WIENCKE (1999) The effect of ultraviolet radiation on photosynthesis and ultravioletabsorbing substances in the endemic Arctic macroalga Devaleraea ramentacea (Rhodophyta). Physiologia Plantarum 105: 58-66.

KIRK JTO (1994) Light and photosynthesis in aquatic ecosystems. Second edition. Cambridge University Press, Cambridge, United Kingdom. 509 pp.

KRAUSE GH \& E WEIS (1991) Chlorophyll fluorescence and photosynthesis: the basics. Annual Review of Plant Physiology and Plant Molecular Biology 42: 313-349.

LITTLER MM \& KE ARNOLD (1982) Primary productivity of marine macroalgal functional-form groups from southwestern North America. Journal of Phycology 18: 307-311.

MANSILLA A, C WERLINGER, M PALACIOS, NP NAVARRO \& P CUADRA (2006) Effects of UVB radiation on the initial stages of growth of Gigartina skottsbergii, Sarcothalia crispata and Mazzaella laminarioides (Gigartinales, Rhodophyta). Journal of Applied Phycology 18: 451-459.

NEWMAN PA, BJ JOHNSON, D LUBIN, SJ OLTMANS \& RC SCHNELL (2007): 2006 Austral springtime ozone depletion. In: Arguez A (ed) State of the climate in 2006: S77-S79. Bulletin of the American Meteorological Society, Boston, Massachusetts, USA.

PAVIA H, G CERVIN, A LINDGREN \& P AABERG (1997) Effects of UV-B radiation and simulated herbivory on phlorotannins in the brown alga Ascophyllum nodosum. Marine Ecology Progress Series 157: 139-146.

POOLE LJ \& JA RAVEN (1997) The biology of Enteromorpha. In: Round FE \& DJ Chapman (eds) Progress in phycological research: 11-48. Biopress Ltd., Bristol, United Kingdom.

PROVASOLI L (1968) Media and prospects for cultivation of marine algae. In: Watanabe A \& A Hattori (eds) Cultures and collections of algae: 47-74. Japanese Society of Plant Physiology, Tokyo, Japan.

RAUTENBERGER R \& K BISCHOF (2006) Impact of temperature on UV-susceptibility of two Ulva (Chlorophyta) species from Antarctic and subantarctic regions. Polar Biology 29: 988-996.

RAUTENBERGER R \& K BISCHOF (2008) UVsusceptibility of photosynthesis of adult sporophytes of four brown Antarctic macroalgae (Phaeophyceae). In: Wiencke C, G Ferreyra, D Abele \& S Marenssi (eds) The Antarctic ecosystem of Potter Cove, King-George Island (Isla 25 de Mayo). Synopsis of research performed 1999-2006 at the Dallmann Laboratory and Jubany Station, Reports on Polar and Marine Research: 263-269. 
Alfred Wegener Institute for Polar and Marine Research, Bremerhaven, Germany.

RUSSELL AW, C CRITCHLEY, SA ROBINSON, LA FRANKLIN, GGR SEATON, WS CHOW, JM ANDERSON \& CB OSMOND (1995) Photosystem II regulation and dynamics of the chloroplast D1 protein in Arabidopsis leaves during photosynthesis and photoinhibition. Plant Physiology 107: 943952.

SAROUSSI S \& S BEER (2007) Alpha and quantum yield of aquatic plants derived from PAM fluorometry: Uses and misuses. Aquatic Botany 86: 89-92.

SCHREIBER U, W BILGER \& C NEUBAUER (1994) Chlorophyll fluorescence as a non-intrusive indicator for rapid assessment of in vivo photosynthesis. In: Schulze E-D \& MM Caldwell (eds) Ecophysiology of photosynthesis: 49-70. Springer-Verlag, Heidelberg, Germany.

STOLARSKI RS, MR SCHOEBERL, PA NEWMAN, RD MCPETERS \& AJ KRUEGER (1990) The 1989 Antarctic ozone hole as observed by TOMS . Geophysical Research Letters 17: 1267-1270.

Associate Editor: Vivian Montecino

Received January 1, 2008; accepted September 25, 2008
TEDETTI M \& R SEMPÉRÉ (2006) Penetration of ultraviolet radiation in the marine environment: a review. Photochemistry and Photobiology 82: 389397.

THOMPSON AM (1991) New ozone hole phenomenon. Nature 352: 282-283.

VASS I (1997) Adverse effects of UV-B light on the structure and function of the photosynthetic apparatus. In: Pessarakli M (ed) Handbook of photosynthesis: 931-949. Marcel Dekker Inc., New York, New York, USA.

WEYKAM G, I GÓMEZ, C WIENCKE, K IKEN \& H KLÖSER (1996) Photosynthetic characteristics and $\mathrm{C}: \mathrm{N}$ ratios of macroalgae from King George Island (Antarctica). Journal of Experimental Marine Biology and Ecology 204: 1-22.

WIENCKE C, MN CLAYTON, I GÓMEZ, K IKEN, UH LÜDER, CD AMSLER, U KARSTEN, D HANELT, K BISCHOF \& K DUNTON (2007) Life strategy, ecophysiology and ecology of seaweeds in polar waters. Reviews in Environmental Science and Biotechnology 6: 95-126. 
